\title{
APAKAH UMR MEMPENGARUHI PENYERAPAN TENAGA KERJA : PENDEKATAN MODEL DEMOMETRIK
}

\author{
Does UMR affects labor absorption's : A Demometric Models Approach
}

\section{Arief Rahman \\ Hakim'}

Aston Pakpahan ${ }^{2}$

\author{
IProdi Agribisnis \\ Faperta Universitas \\ PGRI Palangka Raya \\ 2Prodi Manajemen FEB \\ Universitas Palangka \\ Raya
}

\section{Kata Kunci: \\ Tenaga Kerja, \\ Pertumbuhan Ekonomi, Investasi, UMR, \\ Penduduk. \\ Keywords: \\ Labor, Economic Growth, Investment, UMR, \\ Population}

\section{Accepted}

Maret 2021

\begin{abstract}
Abstrak
Salah satu tujuan dalam pembangunan daerah dan pembangunan nasional adalah penyerapan tenaga kerja dan penurunan pengangguran. Studi tentang penyerapan tenaga kerja selama ini hanya dilakukan dengan pendekatan ekonomi (economic base) yang melihat aspek tenaga kerja dari sisi permintaan saja. Kondisi ini kurang lengkap karena mengabaikan sisi penawaran. Perlu dilakukan studi yang lebih komprehensif dari aspek ekonomi sebagai sisi permintaan dan aspek demografi sebagai sisi penawaran. Pendekatan ini dikenal sebagai model Demometrik.

Penelitian bertujuan mengkaji faktor-faktor yang mempengaruhi penyerapan tenaga kerja dengan model demometrik. Aspek ekonomi yang dikaji adalah investasi dan tingkat upah, sedangkan aspek demografi yang diteliti adalah jumlah penduduk. Data yang digunakan dalam penelitian ini berasal dari seluruh 14 kabupaten/kota di Provinsi Kalimantan Tengah pada periode 2010 - 2019 (9 tahun, dikurangi data tahun 2016). Analisis data dilakukan dengan regresi linear berganda data panel sederhana.

Hasil penelitian menunjukkan bahwa variabel investasi dan jumlah penduduk berpengaruh posituf dan signifikan terhadap penyerapan tenaga kerja sedangkan upah minimum regional tidak berpengaruh terhadap penyerapan tenaga kerja.
\end{abstract}

\begin{abstract}
One of the goals in regional and national development is to absorb labor and reduce unemployment. So far, studies on labor absorption have only been carried out with an economic approach that looks at the labor aspect from the demand side. This condition is incomplete because it ignores the supply side. There needs to be a more comprehensive study of the economic aspect as the demand side and the demographic aspect as the supply side. This approach is known as the Demometric model.

This study aims to examine the factors that influence employment with a demometric model. The economic aspects studied were investment and wage levels, while the demographic aspect studied was the population. The data used in this study came from all 14 districts / cities in Central Kalimantan Province in the 2010 2019 period (9 years, minus 2016 data). Data analysis was performed using multiple linear regression of simple panel data.
\end{abstract}

The results showed that the investment variables and population had a positive and significant effect on labor absorption, while the regional minimum wage had no effect on labor absorption.

Published

April 2021

(C) 202I The Authors. Published by Institute for Research and Community Services Universitas Muhammadiyah Palangkaraya. This is Open Access article under the CC-BY-SA License (http://creativecommons.org/licenses/by-sa/4.0/).

Tujuan kebijaksanaan makroekonomi adalah menciptakan output nasional yang tinggi dengan laju pertumbuhan yang cepat, membuka lapangan kerja dan Parkin, 20I2). Di antara berbagai tujuan makroekonomi tersebut, penciptaan lapangan kerja (dan pengurangan pengangguran) merupakan masalah yang paling sedikit diteliti. Dalam berbagai teori dan model pembangunan yang disusun para ekonom, sebagian besar bertumpu pada peningkatan output, investasi (capital), stabilisasi harga dan perkembangan teknologi (Todaro dan Smith, 2015). Dalam hubungannya dengan pengangguran, mengurangi pengangguran, tingkat harga yang stabil serta menciptakan perdagangan internasional yang menguntungkan (Samuelson dan Nordhaus, 1999; terdapat dua isu utama. Pertama adalah faktor-faktor yang menyebabkan adanya pengangguran yang dihubungkan dengan kegagalan pasar, proses matching antara angkatan kerja dan pekerjaan yang tersedia, dan tidak berlakunya hukum Walras dalam pasar kerja yang menunjukkan adanya sumber daya manusia yang terbuang. Isu mengenai pengangguran yang kedua adalah terkait dengan siklus pasar tenaga kerja yang 
yang dihubungkan dengan perekonomian suatu Negara (Haidy dkk., 20l2). Isu yang kedua ini berkaitan dengan pasar tenaga kerja yang mencakup permintaan dan penawaran tenaga kerja (Parkin, 20I2). Permintaan tenaga kerja berkaitan dengan faktor-faktor ekonomi seperti output nasional. Ketika output nasional meningkat, maka permintaan tenaga kerja juga akan meningkat dan sebaliknya ketika terjadi resesi tingkat pengangguran akan meningkat (Hakim, 200I; Kahpaiboon dkk., 20l0).

Namun dalam teori ekonomi makro terdapat fenomena "Kurva Phillips" yang disumbangkan oleh A.W. Phillips tahun 1958, yang menerangkan terjadinya trade off antara kebijakan mengurangi pengangguran dengan kebijakan mengurangi inflasi. Ini berarti, kebijakan pemerintah untuk mengurangi inflasi akan berdampak pada peningkatan pengangguran (Samuelson dan Nordhaus, 1997). Dalam studi empiris, teori “kurva Phillips" tersebut belum sepenuhnya terbukti karena ada migrasi, perbedaan upah dan lebih kuat dipengaruhi inflasi (Maichal, 2012; Parkinson, 2017).

Dari sisi penawaran, tenaga kerja yang ditawarkan dipengaruhi oleh faktor demografi seperti jumlah dan pertumbuhan serta migrasi penduduk (Todaro dan Smith, 20I5; Mansur dkk., 20I5). Dengan demikian keterkaitan antara pertumbuhan ekonomi dengan pertumbuhan penduduk cukup rumit namun sekaligus sangat menarik. Pertumbuhan penduduk sekaligus akan menambah jumlah faktor produksi dalam menghasilkan output. Namun jika faktor produksi tersebut tidak bisa dimanfaatkan (tidak terserap dalam proses produksi), maka akan berbalik menjadi beban berupa pengangguran. Jumlah penduduk yang bertambah juga berarti bertambahnya pasar yang bisa merangsang peningkatan output nasional. Pada saat yang sama, pertumbuhan output juga akan merangsang penggunaan seluruh faktor produksi di mana salah satu diantaranya adalah penyerapan tenaga kerja.

Berbagai studi empiris telah dilakukan untuk mengetahui faktor-faktor yang mempengaruhi penyerapan tenaga kerja baik di Indonesia maupun di luar negeri. Ringkasan dari berbagai hasil penelitian di atas disajikan dalam tabel I berikut.

Tabel 1. Ringkasan Hasil Penelitian tentang Variabel yang mempengaruhi Penyerapan Tenaga Kerja

\begin{tabular}{|c|c|c|c|c|c|c|}
\hline No. & $\begin{array}{r}\text { Variabel } \\
\text { dijelas }\end{array}$ & $\begin{array}{l}\text { ang } \\
\text { an }\end{array}$ & Variabel Penjelas & $\begin{array}{c}\text { Lokasi dan } \\
\text { Waktu Studi }\end{array}$ & Peneliti & $\begin{array}{l}\text { Sumber/ } \\
\text { Referens }\end{array}$ \\
\hline \multirow[t]{2}{*}{1.} & $\begin{array}{l}\text { Penyerapan } \\
\text { kerja }\end{array}$ & tenaga & Upah & $\begin{array}{l}\text { Nasional/33 } \\
\text { propinsi }\end{array}$ & $\begin{array}{l}\text { Sulistiawati } \\
\text { (2012) }\end{array}$ & $\begin{array}{l}\text { Sulistiawati } \\
\text { (2012) }\end{array}$ \\
\hline & & & & $2006-2010$ & & \\
\hline 2. & $\begin{array}{l}\text { Penyerapan } \\
\text { kerja }\end{array}$ & tenaga & $\begin{array}{l}\text { Produktifitas, upah riil, } \\
\text { pertumbuhan ekonomi }\end{array}$ & $\begin{array}{l}\text { Jawa Tengah, } \\
2012\end{array}$ & $\begin{array}{l}\text { Tambunsaribu } \\
\text { (2013) }\end{array}$ & $\begin{array}{l}\text { Rochmani } \\
(2016)\end{array}$ \\
\hline 3. & $\begin{array}{l}\text { Penyerapan } \\
\text { kerja }\end{array}$ & tenaga & Pertumbuhan ekonomi & $\begin{array}{l}\text { Kalsel, } \\
2002-2012\end{array}$ & $\begin{array}{l}\text { Yunani dan } \\
\text { Mursinta (2014) }\end{array}$ & $\begin{array}{l}\text { Rochmani } \\
\text { (2016) }\end{array}$ \\
\hline 4. & Penyerapan & tenaga & PDRB riil, upah riil, harga & Lampung & Sobita & Rochmani \\
\hline
\end{tabular}




\begin{tabular}{|c|c|c|c|c|c|c|}
\hline & kerja & & $\begin{array}{l}\text { modal pertanian, indeks } \\
\text { harga }\end{array}$ & & Saputra (2014) & (2016) \\
\hline 5. & $\begin{array}{l}\text { Penyerapan } \\
\text { kerja }\end{array}$ & tenaga & Upah & $\begin{array}{l}\text { Amerika Latin, } \\
2002-2012\end{array}$ & $\begin{array}{l}\text { Greer, Castrejon } \\
\text { dan Lee (2014) }\end{array}$ & $\begin{array}{l}\text { Rochmani } \\
(2016)\end{array}$ \\
\hline 6. & $\begin{array}{l}\text { Penyerapan } \\
\text { kerja }\end{array}$ & tenaga & $\begin{array}{l}\text { Jumlah unit } \\
\text { investasi }\end{array}$ & $\begin{array}{l}\text { Wajo, Sulawesi } \\
\text { Selatan }\end{array}$ & $\begin{array}{l}\text { Munasriah } \\
\text { (2015) }\end{array}$ & $\begin{array}{l}\text { Rochmani } \\
\text { (2016) }\end{array}$ \\
\hline 7. & $\begin{array}{l}\text { Penyerapan } \\
\text { kerja }\end{array}$ & tenaga & $\begin{array}{l}\text { Inflasi, PDRB, } \\
\text { Minimum }\end{array}$ & $\begin{array}{ll}\text { Bali, } & 1994 \\
2003 & \end{array}$ & $\begin{array}{l}\text { Indradewa } \\
(2015)\end{array}$ & $\begin{array}{l}\text { Rochmani } \\
\text { (2016) }\end{array}$ \\
\hline 8. & $\begin{array}{l}\text { Penyerapan } \\
\text { kerja }\end{array}$ & tenaga & $\begin{array}{l}\text { Pertumbuhan ekonomi, } \\
\text { upah minimum, jumlah } \\
\text { unit usaha }\end{array}$ & $\begin{array}{l}\text { Jawa Tengah } \\
2001-2014\end{array}$ & $\begin{array}{l}\text { Rochmani } \\
(2016)\end{array}$ & $\begin{array}{l}\text { Rochmani } \\
\text { (2016) }\end{array}$ \\
\hline 9. & $\begin{array}{l}\text { Penyerapan } \\
\text { kerja }\end{array}$ & tenaga & $\begin{array}{l}\text { Pengurangan } \\
\text { penghasilan, } \\
\text { pemerintah }\end{array}$ & $\begin{array}{l}26 \text { negara } \\
\text { OECD, } 2016\end{array}$ & $\begin{array}{l}\text { Duval dan } \\
\text { Furceri (2018) }\end{array}$ & $\begin{array}{l}\text { Duval dan } \\
\text { Furceri (2018) }\end{array}$ \\
\hline
\end{tabular}

Sumber : Telaah Pustaka

Seluruh penelitian di atas hanya melihat pasar tenaga kerja dari sudut pandang ekonomi, (economic-base). Pada umumnya, pendekatan economic-base mempertimbangkan dampak pertumbuhan penduduk melalui peningkatan konsumsi rumah tangga, namun mengabaikan dampak rumah tangga dalam penyediaan tenaga kerja. Pendekatan tradisional economic-base ini tidak cukup untuk menggambarkan kondisi sebenarnya dari pasar tenaga kerja sehingga tidak bisa secara lengkap memberikan arah kebijakan yang harus diambil pemerintah. Berbeda dengan penelitian sebelumnya, penelitian ini akan melihat penyerapan tenaga kerja dari sisi permintaan dan sisi penawaran.

\section{Metode}

Penelitian ini menggunakan model demometrik yang merupakan gabungan dari pendekatan ekonomi dan demografi dalam satu model. Sitanggang dan Noachrowi (2004) telah menyusun model demometrik ketenagakerjaan sebagai berikut :

$$
\mathrm{TK}=f(\mathrm{P}, \delta \mathrm{M}, \mathrm{Y}, \mathrm{UM})
$$

Sementara itu, penelitian Hakim (2001)

menyusun model empiris sebagai berikut :

$$
\mathrm{Y} \quad=f(\mathrm{IG}, \mathrm{IP}, \mathrm{PG})
$$

Variabel-variabel dalam persamaan tersebut adalah :

$$
\begin{array}{ll}
\mathrm{TK} & =\text { Penyerapan Tenaga Kerja } \\
\mathrm{P} & =\text { Populasi } \\
\delta \mathrm{M} & =\text { Net Migran (Migrasi }
\end{array}
$$

masuk - migrasi keluar)

$$
\begin{array}{ll}
\mathrm{Y} & =\text { PDRB } \\
\mathrm{UM} & =\text { Upah Minimun } \\
\mathrm{IG} & =\text { Investasi Pemerintah } \\
\mathrm{IP} & =\text { Investasi Privat } \\
\text { PG } & =\text { pertumbuhan Pupulasi }
\end{array}
$$

Substitusi persamaan (2) ke dalam persamaan (1) akan menghasilkan model matematis sebagai berikut :

$$
\mathrm{TK}=f(\mathrm{P}, \delta \mathrm{M}, \mathrm{IG}, \mathrm{IP}, \mathrm{UM})
$$


Selanjutnya variabel Penduduk (P) dan net migrasi $(\delta \mathrm{M})$ digabungkan menjadi variabel Penduduk (P) saja dan variabel Investasi Publik (IP) dengan Investasi Pemerintah (IG) disatukan menjadi satu variabel, yaitu investasi (PMTB), sehingga persamaan (3) menjadi

$\mathrm{TK}=f(\mathrm{PMTB}, \mathrm{P}, \mathrm{UM})$

Persamaan (4) selanjutnya ditransformasikan ke dalam model ekonometrik

TK $=\mathrm{a}_{1}+\mathrm{a}_{2} \mathrm{PMTB}+\mathrm{a}_{3} \mathrm{P}+$ $\mathrm{a}_{4} \mathrm{UM}+\mu$

Jenis dan sumber data yang dipergunakan dalam penelitian ini adalah :

a. Data jumlah tenaga kerja (TK) diambil dari Buku Statistik Ketenagakerjaan Propinsi Kalimantan Tengah

b. Data investasi diperoleh dari data Pembentukan Modal Tetap Bruto (PMTB) yang diperoleh dari Buku PDRB Kabupaten/Kota menurut Penggunaan

c. Data jumlah penduduk (P) diperoleh dari Buku Kalimantan Tengah Dalam Angka

d. Data Upah Minimum Regional (UM) diambil dari Buku Statistik Ketenagakerjaan Propinsi Kalimantan Tengah

Data yang digunakan dalam penelitian ini berasal dari seluruh 14 kabupaten/kota di
Provinsi Kalimantan Tengah pada periode 2010 s/d 2019 (9 tahun - karena data 2016 tidak tersedia). Data dimaksud diperoleh dari berbagai penerbitan Badan Pusat Statistik. Alat analisis yang digunakan dalam penelitian ini adalah regresi linier berganda data panel sederhana dengan model time series autocorrelation (Pendyck dan Rubinfeld, 1998). Analisis data dilakukan dengan melakukan estimasi model ekonometrik yang telah disusun dengan data-data empiris yang telah dikumpulkan. Alat analisis yang digunakan dalam penelitian ini adalah regresi linear berganda data panel sederhana. Estimasi dilakukan dengan metode Ordinary Least Square (OLS) dengan perangkat lunak Eviews. Koefisien parameter dinyatakan kuat jika model hasil estimasi telah lolos dari uji asumsi klasik. Pengujian parameter dilakukan dengan menggunakan $p$ value (yang disediakan oleh perangkat lunak Eviews). Kaidah yang digunakan adalah semakin kecil $p$ value semakin kuat penolakan terhadap hipotesis nol (Gujarati dan Porter, 2010).

\section{Hasil Analisis}

Hasil estimasi model yang dilakukan dengan Eviews disajikan sebagai berikut

Tabel 2. Hasil Estimasi Faktor yang mempengaruhi Penyerapan Tenaga Kerja di Kalimantan

Tengah Tahun 2010 - 2019 dengan pendekatan OLS

\begin{tabular}{clcc}
\hline No & \multicolumn{1}{c}{ Variabel Penjelas } & Keefisien & Probabilitas \\
\hline 1 & Konstanta & 1994.448 & 0.5743 \\
2. & PMTB & 0.800018 & 0.0477 \\
\hline
\end{tabular}




\begin{tabular}{llll} 
3. & P & 0.439250 & 0.0000 \\
4. & UMR & 0.000918 & 0.5992 \\
\hline
\end{tabular}

Sumber : Analisis Data

$\mathrm{R}^{2}=0,979445$ Adjusted $\mathrm{R}^{2}=0,978810 \quad$ F-Statistik $=1540,708 \quad \mathrm{D}-\mathrm{W}=2,296658$

1. Otokorelasi (LM test) $\mathrm{X}^{2}=2,168723(p$ value $=0,338118)$

2. Normalitas (JB test) $\mathrm{X}^{2}=3311,78$ ( $p$ value $\left.=0,000000\right)$

3. Linearitas (Ramsay Reset test) $\mathrm{F}=1,046688$ ( $p$ value $=0,302755)$

4. Heteroskesdasitisitas (White test) $\mathrm{X}^{2}=36,47133$ ( $p$ value $\left.=0,229240\right)$

Hasil pengujian multikolinieritas yang dilakukan dengan regresi parsial secara berpasangan (Farrar dan Glauber) menghasilkan nilai $\mathrm{R}^{2}$ masing-masing regresi seperti disajikan dalam tabel 3.

Tabel 2 : Koefisien Determinan (R2) Regresi Parsial antar Variabel Penjelas

Nilai $\mathrm{R}^{2}$ awal $\quad=0,979445$

\begin{tabular}{|c|c|c|c|}
\hline Variabel & PMTB & $\mathbf{P}$ & UMP \\
\hline PMTB & 1,000000 & 0,036423 & 0,000282 \\
\hline $\mathbf{P}$ & & 1,000000 & 0,021147 \\
\hline UMP & & & 1,000000 \\
\hline
\end{tabular}

Sumber : Hasil analisis

Analisis Statistik dan Ekonometrik

a. Uji ketepatan perkiraan (Goodness of fit)

Hasil perhitungan menunjukkan nilai $\mathrm{R}^{2}$ sebesar 0,979445, hal ini berarti $97,94 \%$ dari variasi dependent variable dapat diterangkan oleh himpunan variasi independent variable. Nilai ketepatan perkiraan ini cukup mengingat sifat data lintas sektor yang cenderung mempunyai variasi besar.

b. Uji koefisien regresi serentak Nilai F-statistik sebesar 1540,708 ( $p$ value $=0,000000)$ menunjukkan bahwa semua variabel penjelas yang terdiri dari PMTB, $\mathrm{P}$ dan UMP secara bersama-sama mempengaruhi penyerapan tenaga kerja selama periode penelitian.

c. Uji koefisien regresi individual Berdasarkan hasil estimasi, tidak semua variabel penjelas secara individual mempengaruhi penyerapan tenaga kerja sektopral selama periode penelitian. Variabel PMTB dan $\mathrm{P}$ secara signifikan mempengaruhi penyerapan tenaga kerja. Hal ini terlihat dari $p$ value kedua variabel penjelas yang mempunyai nilai kurang 
dari 0,05 sehingga pada $\alpha=5 \%$ kedua variabel penjelas signifikan secara statistik. Di samping signifikan secara statistik, koefisien regresi juga menghasilkan tanda yang dikehendaki teori ekonomika. Namun berdasarkan hasil estimasi ternyata variabel UMP tidak berpengaruh terhadap penyerapan tenaga kerja. Hal ini dapat dilihat dari nilai $p$ value sebesar 0.5992 (lebih tinggi dari 0,05) sehingga pada derajat kepercayaan $5 \%$ hipotesis bahwa upah minimum regional (UMP) berpengaruh terhadap penyerapan tenaga kerja telah ditolak.

d. Uji asumsi klasik

Uji asumsi klasik terhadap model meliputi uji otokorelasi, uji normalitas, uji linearitas, uji heteroskedastisitas dan uji multikolinieritas. Uji otokorelasi dengan Durbin-Watson test menghasilkan nilai $\mathrm{D}-\mathrm{W}$ sebesar 2,296658 yang pada derajat $\alpha=5 \%$ terletak di areal ragu-ragu. Ini berarti uji D-W tidak bisa digunakan dalam model ini. Pengujian otokorelasi dengan uji LM menghasilkan nilai $\mathrm{X}^{2}$ $=2,168723$ dengan $p$ value 0,330118 sehingga pada $\alpha=5 \%$ dapat dinyatakan bebas dari otokorelasi.

Uji normalitas dengan Jarque-Bera $(J B)$ test menghasilkan nilai $\mathrm{X}^{2}$ sebesar 3311,78 ( $p$ value 0,000000) sehingga pada $\alpha=0,05$, asumsi distribusi normal ditolak. Namun demikian, sesuai dengan kaidah central limit theorem (CLT), sampel dapat dinyatakan berdistribusi normal karena mempunyai jumlah observasi yang besar (Gujarati dan Porter, 2010).
Uji linearitas dengan Ramsay Reset test menghasilkan nilai $\mathrm{F}$ sebesar 1,046688 dengan $p$ value $=0,307355$, maka pada $\alpha=0,05$ asumsi linearitas dapat dipenuhi. Uji heteroskedastisitas dengan White test menghasilkan nilai $\mathrm{X}^{2}$ sebesar 36,47133 dengan $p$ value $=$ 0,229240 sehingga pada $\alpha=0,05$, masalah heteroskesdastisitas tidak ditemukan. Uji asumsi klasik terakhir adalah uji multikolinearitas yang dilakukan dengan melakukan regresi linear antar variabel penjelas. Koefisien determinan $\left(\mathrm{R}^{2}\right)$ hasil regresi antar variabel penjelas yang disajikan pada tabel 2 menunjukkan nilai $\mathrm{R}^{2}$ hasil regresi tersebut jauh lebih kecil dari nilai $\mathrm{R}^{2}$ pada regresi awal, dengan demikian multikolinearitas tidak terjadi

Dengan demikian, model dapat dinyatakan bebas dari masalah otokorelasi, heteroskedastisitas dan multikolineritas serta memenuhi asumsi linearitas dan berdistribusi normal. Hal ini berarti model dapat dipilih sebagai model empiris.

\section{Pembahasan}

Pengaruh investasi. Hasil penelitian menunjukkan bahwa investasi (yang diukur dengan Pembentukan Modal Tetap Bruto/PMTB) berpengaruh positif dan signifikan terhadap penyerapan tenaga kerja (koefisien regresi sebesar 0,800018 dan sigmifikan pada level $\alpha=0,05$ ). Berarti jika terjadi investasi sebesar Rp. 800 juta maka akan terjadi peningkatan penyerapan tenaga kerja sebanyak 1 (satu) orang. Penelitian ini sesuai dengan hasil penelitian Munasriah 
(2015) di Sulawesi Selatan (dikutip dari Rochmani, 2016) dan penelitian Rochmani (2016) di Bali yang menyatakan bahwa penambahan unit usaha akan meningkatkan penyerapan tenaga kerja. Hasil ini juga mendukung penemuan Duval dan Furceri (2018) yang menemukan bahwa investasi pemerintah dapat meningkatkan penyerapan tenaga kerja.

Secara sederhana dapat dijelaskan bahwa kegiatan investasi akan meningkatkan kapasitas produksi yang membutuhkan tenaga kerja baru untuk menjalankannya. Namun demikian, koofisien regresinya sangat tinggi, sehingga kebutuhan investasi per tambahan 1 (satu) orang tenaga kerja sangat tinggi, lebih tinggi dibanding penelitian serupa di Provinsi Jawa Tengah yang koefisiennya secara keseluruhan 0,32 (Romdhoni, 2017) dan khusus sector industry koefisiennya sebesar 0,0587 (Chusna, 2013). Dalam penelitian ini tidak dibedakan investasi untuk penyediaan infrastruktur dan investasi non infrastruktur. Kondisi Provinsi Kalimantan Tengah yang masih "miskin infrastruktur" diduga menjadi penyebab tingginya koefisien regresi ini. Apalagi wilayah Kalimantan Tengah sangat luas (5 kali luas Pulau Jawa). Hasil penelitian ini mendukung kesimpulan Knight dkk. (1993), Ghura dan Hadjimichael (1996) serta Dessus dan Herrera (2000) bahwa efek marjinal investasi di wilayah yang sedang berkembang lebih rendah dibandingkan efek marjinal investasi di wilayah yang sudah maju.

Pengaruh jumlah penduduk. Hasil penelitian menunjukkan bahwa jumlah penduduk berpengaruh positif dan signifikan terhadap penyerapan tenaga kerja (koefisien regresi sebesar 0,439250 dan sigmifikan pada level $\alpha=0,05)$. Berarti jika terjadi pertambahan penduduk sebanyak 4.392 orang maka akan terjadi peningkatan penyerapan tenaga kerja sebanyak 100 (seratus) orang. Hasil penelitian ini sesuai dengan penelitian Mansur dkk. (2015) yang menyatakan bahwa pertambahan penduduk melalui imigrasi tenaga kerja berkorelasi dengan penyerapan tenaga kerja di perkebunan kelapa sawit di Sabah, Malaysia. Penelitian Sitanggang dan Nachrowi (2004) juga mengkonfirmasi peranan perubahan populasi terhadap penyerapan tenaga kerjadan kemungkinan akan dipengaruhi juga oleh perubahan struktur ekonomi. Pertumbuhan penduduk akan memberi tekanan terhadap perekonomian daerah dan akan mengurangi tingkat tabungan (Parkin, 2012) namun Setiati (1996) menemukan pengaruh positif pertumbuhan penduduk terhadap pertumbuhan ekonomi di 14 provinsi yang jarang penduduknya. Pertumbuhan penduduk akan menggerakkan pemanfaatan potensi ekonomi pada wilayah yang jarang penduduknya. Aktivitas ekonomi tersebut akan memicu kenaikan permintaan barang dan jasa, sehingga para pelaku usaha akan menambah jumlah tenaga kerjanya. Kepadatan penduduk Provinsi Kalimantan Tengah tahun 2019 adalah 18 jiwa per km2, dan dengan luas wilayah yang sangat besar selalu tersedia lapangan kerja bagi oara penduduknya.

Pengaruh Upah Minimum Regional. Hasil penelitian menunjukkan bahwa Upah Minimum Regional tidak berpengaruh terhadap penyerapan tenaga kerja. orang. 
Hasil penelitian ini sama dengan hasil penelitian Sandika dkk. (2014) di Kabupaten Palalawan. Namun beberapa peneliti lain menunjukkan hasil yang berbeda. Penelitian Chusna (2013) di Jawa Tengah menunjukkan bahwa upah berpengaruh positif terhadap penyerapan tenaga kerja, sementara penelitian Basriwijaya dan Maryoni (2015) di Provinsi Sumatra Utara menemukan bahwa kenaikan upah akan mengurangi penyerapan tenaga kerja. Sesuai hukum permintaan - penawaran, kenaikan upah akan meningkatkan penawaran tenaga kerja dan pada saat yang sama akan menurunkan permintaan tenaga kerja. Namun karena kontrak kerja dari para pekerja, maka dalam hukum Keynesian, para pekerja tidak bisa diberhentikan dan pada saat yang sama, pengusaha akan menahan diri untuk tidak menerima pegawai baru. Ini terjadi karena pasar tenaga kerja yang rigid (kaku) dan tidak mudah berubah karena perubahan harga (Parkin, 2012). Sulistiani (2012) dan Basriwijaya dan Maryoni (2015) memberikan penjelasan terhadap fenomena turunnya penyerapan tenaga kerja ketika upah naik, bahwa ketika upah dinaikkan, para pekerja sector informal dan pekerja sector pertanian (yang mempunyai keahlian cukup baik) akan melepaskan pekerjaannya dan mencoba masuk ke pekerjaan sector formal karena adanya kenaikan upah tadi (sesuai hukum penawaran). Oleh fenomena itu, kenaikan upah justru akan menurunkan serapan tenaga kerja (setidaknya akan stagnan tidak naik).

\section{Kesimpulan}

Hasil penelitian ini menunjukkan bahwa investasi dan pertumbuhan penduduk berpengaruh positif dan signifikan terhadap penyerapan tenaga kerja di Provinsi Kalimantan Tengah selama periode penelitian. Namun demikian, tingkat efisiensi investasi dalam penyediaan lapangan kerja di Kalimantan Tengah masih rendah dibandingkan daerah lain yang sudah diteliti (Provinsi Jawa Tengah). Sementara itu, upah minimum regional (UMR) tidak berpengaruh secara nyata terhadap penyerapan tenaga kerja karena pasar tenaga kerja yang kaku (rigid).

Meskipun demikian, penelitian ini hanya mencakup wilayah yang terbatas dan penyerapan tenaga secara keseluruhan. Pada masa mendatang diharapkan dapat dilakukan penelitian dalam skala yang lebih luas (misalnya seluruh wilayah di Pulau Kalimantan) dan penyerapan tenaga kerja secara sectoral.

\section{Ucapan Terima Kasih}

Tim Peneliti mengucapkan penghargaan dan terima kasih kepada Kementrian Riset dan Teknologi/Badan Riset dan Inovasi Nasional yang telah menyediakan biaya bagi penelitian ini. Ucapan dan penghargaan yang sama juga ditujukan kepada Badan Pusat Statistik Kalimantan Tengah terutama Ibu Monica yang sepenuh hati membantu pengumpulan data untuk penelitian ini.

\section{Daftar Pustaka}

Basriwijaya, K.M.Z. dan H.S. Maryoni. 2015. "Pengaruh Investasi, Inflasi, Suku Bunga dan Tingkat Upah terhadap Penyerapan Tenaga Kerja di Sektor Pertanian Provinsi Sumatra Utara" Jurnal Ilmiah Cano Ekonomos 4 (2) : 89 - 96

Chusna, A. 2013. "Pengaruh Laju Pertumbuhan Sektor Industri, Investasi dan 
Upah terhadap Penyerapan Tenaga Kerja Sektor Industri di Jawa Tengah Tahun 1980 - 2011" Economics Development Analysis Journal 2 (3) : 14-23

Dessus, S. dan R. Herrera. 2000. "Public Capital and Growth Revisited: A Panel Data Assesment". Economic Development and Cultural Change. 48 (2) 407-418.

Duval, R. dan D. Furceri. 2018. "The Effect of Labor Market and Product Market Reforms: The Role of Macroeconomic Conditions and Policies" IMF Econ Rev. 66 : $31-69$.

Ghura. D. dan M.T. Hadjimichael. 1996. "Growth in Sub Sahara Africa" IMF Staff Paper. 43 (3) : 605-634.

Gujarati, D.N. dan D.C. Porter. 2010. Dasar-Dasar Ekonometrika. Edisi kelima. Salemba Empat. Jakarta.

Haidy, N., A. Pasay dan R. Indrayanti. 2012. "Pengangguran, Lama Mencari Kerja dan Reservation Wage Tenaga Kerja Terdidik" Jurnal Ekonomi dan Pembangunan Indonesia. 12 (2) : $116-135$.

Hakim, A.R. 2001. "Pengaruh Investasi Swasta, Investasi Publik dan Pertumbuhan Penduduk terhadap Pertumbuhan Ekonomi 26 Propinsi di Indonesia" Tesis PPS Universitas Gadjah Mada (tidak dipublikasikan).

Knight, M., N. Loayza dan D. Villanueva. 1993. "Testing the Neoclassical Theory of Economic Growth" IMF Staff Paper. 40 (3). 512-541.

Kohpaiboon, A., P. Kulthanavit, P. Vijitnopparat dan N. Soonthornchawakan. 2010. "Global Recession, Labor Market Adjustment and International Production Network" ASEAN Economic Bulletin 27 (1) : $98-120$.

Maichal. 2012. "Kurva Phillips di Indonesia" Jurnal Ekonomi Pembangunan. 13 (2) : 183 - 193.
Mansur, K., B. Sareya dan R. Mahmud. 2015. "The Relationship Between Immigration and Labor Market Performance in Sabah's Oil Palm Plantation Sector" Perspectives of Innovation, Economic and Business. 15 (2) : 67 - 77.

Parkin, M. 2012. Macroeconomis. Tenth Edition. Adison - Wesley. Singapore.

Parkinson, C. 2017. "An Examination of the Phillips Curve Using City Level Data" Monthly Labor Review. Februari. 2018.

Pendyck, R.S. dan D.L. Rubinfeld. 1998. Econometric Models and Economic Forecast. Fourth Edition. Irwin/McGrawHill. Singapore.

Rochmani, T.S., Y. Purwaningsih dan A. Suryantoro. 2016. "Analisis Penyerapan Tenaga Kerja Sektor Industri di Provinsi Jawa Tengah" JIEP. 16 (2) : 50-61.

Romdhoni, A.H. 2017. "Pengaruh Investasi terhadap Penyerapan Tenaga Kerja di Jawa Tengah Tahun 2009 - 2013" Jurnal Ilmiah Ekonomi Islam 03 (02) : 139 - 151.

Samelson, P.A dan W.D. Nordhaus. 1997. Makroekonomi. Edisi Keempat belas. Penerbit Erlangga. Jakarta.

Sandika, R.S., Y. Maulida dan D. Setiawan. 2014. "Pengaruh Investasi terhadap Penyerapan Tenaga Kerja di Kabupaten Palalawan" JOM FEKOM. 1 (2) : 1 - 16.

Setiati, I. 1996. "Pengaruh Penggunaan Variabel Demografi dalam Model Pertumbuhan Ekonomi : Kasus 25 Propinsi di Indonesia 1983 - 1992" Ekonomi dan Keuangan Indonesia. 44 (2) : 121 - 162.

Sitanggang, I.R. dan N.D. Nachrowi. 2004. "Pengaruh Struktur Ekonomi pada Penyerapan Kerja Sektoral : Analisis Model Demometrik di 30 Propinsi pada 9 Sektor di Indonesia" Jurnal Ekonomi dan Pembangunan Indonesia. V (01) : 103 133. 
Arief Rahman Hakim dan Aston Pakpahan. Apakah UMR Mempengaruhi Penyerapan Tenaga Kerja : Pendekatan Model Demometrik

Sulistiawati, R., 2012. "Pengaruh Upah Minimum terhadap Penyerapan Tenaga Kerja dan Kesejahteraan Masyarakat di Provinsi di Indonesia" Jurnal EKSOS. 8 (3) : $195-211$.
Todaro, M.P. dan S.C. Smith. 2015. Economic Development. Twentfth Edition. Pearson. Singapore. 